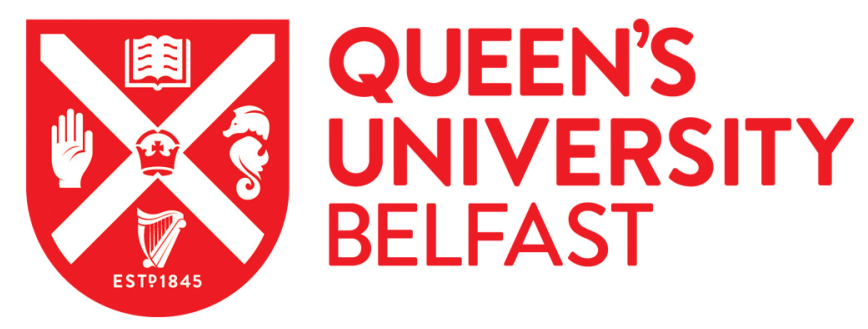

\title{
Promoting Community Renewable Energy in a Corporate Energy World
}

Strachan, P. A., Cowell, R., Ellis, G., Sherry-Brennan, F., \& Toke, D. (2015). Promoting Community Renewable Energy in a Corporate Energy World. Sustainable Development, 23(2), 96-109. https://doi.org/10.1002/sd.1576

Published in:

Sustainable Development

Document Version:

Peer reviewed version

Queen's University Belfast - Research Portal:

Link to publication record in Queen's University Belfast Research Portal

Publisher rights

Copyright (C 2015 John Wiley \& Sons

This is the accepted version of the following article: Strachan, PA, Cowell, R, Ellis, G, Sherry-Brennan, F \& Toke, D 2015, 'Promoting Community Renewable Energy in a Corporate Energy World' Sustainable Development., 10.1002/sd.1576, which has been published in final form at http://onlinelibrary.wiley.com/doi/10.1002/sd.1576/abstract

\section{General rights}

Copyright for the publications made accessible via the Queen's University Belfast Research Portal is retained by the author(s) and / or other copyright owners and it is a condition of accessing these publications that users recognise and abide by the legal requirements associated with these rights.

Take down policy

The Research Portal is Queen's institutional repository that provides access to Queen's research output. Every effort has been made to ensure that content in the Research Portal does not infringe any person's rights, or applicable UK laws. If you discover content in the Research Portal that you believe breaches copyright or violates any law, please contact openaccess@qub.ac.uk. 


\section{Promoting community renewable energy in a corporate energy world}

\section{Peter A. Strachan ${ }^{1}$, Richard Cowell ${ }^{2}$, Geraint Ellis ${ }^{3}$, Fionnguala Sherry-Brennan ${ }^{4}$ and David Toke ${ }^{5}$}

\author{
1 Aberdeen Business School \\ Robert Gordon University \\ Garthdee Road \\ ABERDEEN, AB10 7QE \\ Scotland \\ United Kingdom
}

Tel: (+44) (0)1224 263426

Email: p.a.strachan@rgu.ac.uk

3 School of Planning, Architecture \& Civil Engineering

Queen's University Belfast

David Keir Building

Stranmillis Road

Belfast, BT9 5AG

United Kingdom

Tel: +44 (0) 2890974370

Email: g.ellis@qub.ac.uk

5 Department of Politics and International

Relations

University of Aberdeen

Edward Wright Building

King's College Regents Walk

Aberdeen, AB24 3FX

United Kingdom

Tel: +44 (0) 1224272558

Email: d.toke@abdn.ac.uk
2 School of Planning and Geography

Cardiff University

Glamorgan Building

King Edward VII Avenue

Cardiff, CF10 3WA

United Kingdom

Tel.: +44 (0)2920876684

Email: cowellrj@cardiff.ac.uk

4 Welsh School of Architecture,

Cardiff University

King Edward VII Avenue

Cardiff, CF10 3NB

Tel: +44 (0) 2920879314

Email: sherry-brennanf@cardiff.ac.uk 


\begin{abstract}
Small-scale, decentralised and community-owned renewable energy is widely acknowledged to be a desirable feature of low carbon futures, but faces a range of challenges in the context of conventional, centralised energy systems. This paper draws on transitions frameworks to investigate why the UK has been an inhospitable context for community-owned renewables and assesses whether anything fundamental is changing in this regard. We give particular attention to whether political devolution; the creation of elected governments for Scotland, Wales and Northern Ireland, has effected the trajectory of community renewables. Our analysis notes that devolution has increased political attention to community renewables, including new policy targets and support schemes. However, these initiatives are arguably less important than the persistence of key features of socio-technical regimes: market support systems for renewable energy and land-use planning arrangements that systemically favour major projects and large corporations, and keep community renewables to the margins. There is scope for rolling out hybrid pathways to community renewables, via joint ownership or through community benefit funds, but this still positions community energy as an adjunct to energy pathways dominated by large, corporate generation facilities.
\end{abstract}

\title{
Key words
}

sustainable development, renewable energy, community energy, United Kingdom, devolution, energy transition

\section{Introduction}

In policy debates about sustainable development there is widespread agreement on the need for transition towards more sustainable energy systems, with the European Union (EU) emphasising the expansion of renewable sources. As part of its legally binding climate change and energy package the EU aims to raise the share of energy consumption produced from renewable energy resources to $20 \%$ by 2020 , with the UK's specific target being 15\%. On the $24^{\text {th }}$ October 2014 the European Council approved a new binding target, to increase the share of renewable energy to at least $27 \%$ of the EU's energy consumption by 2030.

A persistent element in these strategies is the promotion of small-scale, decentralised and diversely-owned modes of renewable energy development, with advocates 
highlighting the opportunities for reduced environmental impacts and empowering citizens, compared to conventional systems (Lovins, 1977; Rojanamon et al., 2013). Community engagement in energy provision is also deemed to enhance economic resilience and social capital among the communities involved (e.g. Park, 2012; Lybæk et al., 2013). Interest in community ownership of renewable energy has strong pedigree especially in Denmark and Germany, but this paper is concerned less with refining normative arguments than with examining issues of transition (Hopwood et al., 2005; Li et al., 2013). Thus the question guiding this paper is: how and in what contexts might community renewable energy pathways expand to influence wider systems of energy provision?

It is vital to ask this question in countries where community renewables traditionally have been a marginal feature of energy provision. The UK is a useful case in this respect, especially given the exceptionally low levels of trust by the public in dominant energy utility companies (Edelman, 2014). UK Governments have issued supportive statements about the potential of community renewables (DTI, 2003; DECC, 2014), and the last twenty years have seen a proliferation of small, sustainable energy projects (Harnmeijer et al., 2012). However, the dominant mode of energy provisioning exhibits a persistent 'lock-in to centralisation' (Turcu and Rydin, 2012), with major fossil fuel and nuclear corporations and large-scale infrastructure dominating provision, including renewables (Strachan et al., 2010). In this paper we therefore seek to understand how this essentially corporate energy world configures the opportunities for community renewables to expand. This is a pertinent issue for the UK, but also for other countries, like Australia and parts of the US, where large energy companies are the key players. 
Addressing this question also sheds light on wider questions about the feasibility of expecting community renewables to drive wider system transformation.

Our framework for addressing these questions takes concepts from transition theory, including the widely used multi-level perspective (Geels, 2002). A central concept here is the persistence of 'socio-technical regimes' which - in the case of energy systems are embedded in economic processes, consumption practices, regulatory arrangements and infrastructure. These regimes sustain incumbent actors and structure the scope for change. Change may be triggered by 'niche' innovations, to the extent that they can coalesce and challenge the socio-technical regime. Windows of opportunity can arise from exogenous shifts in society, economy or politics (the 'landscape' level), which destabilise the existing regime. Such theoretical frameworks have been applied to community renewable energy, but much of the existing literature focuses on local projects and local conditions (i.e. the 'niche'). However, niche-to-regime relationships require more analysis (Smith, 2012); not least the way in which government action shapes the scope for community renewables to expand. Moreover, rather than assuming that socio-technical regimes are stable and resistant to change, we follow Verbong and Loorbach (2012) in recognising the need to understand how dominant regimes adapt in the face of niche innovations or shifting social and political conditions. The multi-level perspective allows an appreciation of the complexity of change, including the role of different actors in a transition (Meadowcroft, 2009); policy mechanisms (Alkemade et al., 2011); market design and incentives (Smith Stegen and Seel, 2013); and, potential barriers (Steinhilber et al., 2013). Despite this, our understanding of ongoing transition processes is still rather weak (Späth and Rohracher, 2012), and approaches have been 
criticised for lack of attention to agency, power and politics (Shove and Walker, 2007); and paying insufficient attention to 'social innovation' (Seyfang and Haxeltine, 2012).

We focus on the UK, where a distinctive feature of community renewables has been the influence of devolution. Beginning in 1998, this created new elected assemblies for Northern Ireland, Scotland and Wales, and has seen certain powers pass to them from UK central government. In transition theory terms, one might consider devolution as a major 'landscape' change, with the potential to disrupt prevailing socio-technical regimes for energy. The insertion of this new tier of government may also foster niche innovations by 'creating space for front runners', and helping the development of new coalitions and networks, that might then exert more pressure on business-as-usual (Verbong and Loorbach, 2012). However, the powers of the devolved governments in the energy sphere are circumscribed in various respects by the constitutional settlement (Cowell et al., 2013), viz.:

- Each has significant autonomy over the planning system, by which we mean the drawing up of land use planning policy and overseeing the consenting process for, inter alia, energy projects.

- The devolved governments have more limited scope to influence the form and operation of market support systems for renewable energy - designed to incentivise investment and overcome barriers to entry - for which the UK central government is still the prime mover.

- Each has full control over economic development spending priorities.

- Other key facets of the UK electricity provision system - grid operation, market regulation - are managed by arms length regulatory bodies reporting to UK central government. 
Table 1 outlines in more detail the formal powers held by each of the devolved governments.

\begin{tabular}{|l|l|l|l|l|l|}
\hline Country & $\begin{array}{l}\text { Energy } \\
\text { policy is... }\end{array}$ & $\begin{array}{l}\text { Provision of } \\
\text { market } \\
\text { support for } \\
\text { renewable } \\
\text { energy }\end{array}$ & $\begin{array}{l}\text { Planning and } \\
\text { consents } \\
\text { (onshore) }\end{array}$ & $\begin{array}{l}\text { Planning } \\
\text { and } \\
\text { consents } \\
\text { (offshore) }\end{array}$ & $\begin{array}{l}\text { Economic } \\
\text { development } \\
\text { spending }\end{array}$ \\
\hline $\begin{array}{l}\text { Northern } \\
\text { Ireland }\end{array}$ & $\begin{array}{l}\text { Fully } \\
\text { devolved }\end{array}$ & Fully devolved & Fully devolved & $\begin{array}{l}\text { Fully } \\
\text { devolved }\end{array}$ & Fully devolved \\
\hline Scotland & $\begin{array}{l}\text { Executively } \\
\text { devolved }\end{array}$ & $\begin{array}{l}\text { Scope to shape } \\
\text { delivery of } \\
\text { some schemes }\end{array}$ & Fully devolved & $\begin{array}{l}\text { Fully } \\
\text { devolved }\end{array}$ & Fully devolved \\
\hline Wales & Not devolved & No powers & $\begin{array}{l}\text { Partial powers } \\
\text { over planning } \\
\text { policy and } \\
\text { consent for } \\
\text { smaller } \\
\text { schemes } \\
\text { (below 50MW) }\end{array}$ & $\begin{array}{l}\text { Power to } \\
\text { determine } \\
\text { applications up } \\
\text { to 1MW } \\
\text { (exception } \\
\text { under } \\
\text { Transport \& } \\
\text { Works Act } \\
1992)\end{array}$ & Fully devolved \\
\hline
\end{tabular}

Table 1: Formal energy powers held by Northern Ireland, Scotland and Wales

Whatever the allocation of formal powers, much depends on the capacity or willingness of the devolved governments to challenge dominant UK energy pathways. That they might not is itself revealing about the adaptability of socio-technical regimes and position of community renewables.

The analysis in this paper draws on a research project ${ }^{1}$ that examined the impact of devolution on the delivery of renewable energy in the UK. In the next section we use the idea of energy paths to explore the complexities of transition and address definitional issues of 'community renewables'. We centre our analysis on projects with

\footnotetext{
${ }^{1}$ This project ran from January 2011 to January 2013. It included 80 interviews with government, business and environmental groups, as well as documentary analysis of formal policy statements, submissions to government inquiries and other statements of current renewable policy. This forms the evidence on which this paper has been based.
} 
high levels of community involvement in development and ownership although, as will be shown, definition is constitutive of the scope for expansion. We then examine recent policy initiatives across the UK that encourage community renewables and two dimensions of the socio-technical regime which have persistently disadvantaged it: market support and planning policy. In light of this, we then consider what opportunities for expanding community renewables seem compatible with the persistence of hard energy paths, before examining whether actors that represent community renewables, have been able to act on wider policy structures. The paper concludes with a summary of the key findings.

\section{2. 'Hard' and 'soft' qualities in sustainable energy transitions}

A well-known framework for interpreting energy development is Lovins' 'hard' and 'soft' energy paths (Lovins, 1977). The 'hard path' relies on the continued expansion of complex, large-scale electricity generation technologies (classically nuclear power), with electricity distributed through high voltage grids, using institutional machinery which tends to confer power on centralised bureaucracies and corporate oligopolies whilst marginalising the role of citizens. 'Soft paths' entail more serious consideration of energy efficiency and the pursuit of renewable energy technologies which deliver more flexible, decentralised and locally-tailored energy systems, with greater accessibility to citizens and more dispersed risks.

The concepts of 'soft' and 'hard' energy paths are heuristically useful but only take us so far in explaining change. In reality, there is a plethora of energy development pathways, not a simple binary choice (Verbong and Loorbach, 2012), and any account of transition - such as the capacity for community renewables to expand - needs to recognise this 
scope for hybridity (see Murphy and Smith, 2013). Thus, renewable energy can be delivered through 'hard' or 'soft' pathways, depending on the social relations in which it is enmeshed. Although deeper social engagement is usually seen as a particular strength of soft energy paths, reality may not be so simple (Turcu and Rydin, 2012); for example, decentralised energy provision may not automatically entail the ownership of facilities by local communities. There are active debates about how to engage publics more widely in all energy pathways, with the following quote from the UK government illustrating a common policy belief:

'Projects are generally more likely to succeed if they have broad public support and the consent of local communities. This means giving communities both a say and a stake, in appropriately-sited renewable energy projects' (DECC, 2011: para. 3.25$)$

However, it is not always clear whether advocates of this view are promoting greater community engagement as a transformative project that moves towards soft energy paths, or suggesting that physically unchanged hard energy paths would more readily gain public support if they had more communitarian and democratic involvement. Neither does it suggest what sort of stake or degree of control may be needed to make a project succeed. Moreover, the relationship between prospective public engagement in energy development and levels of social support achieved is mediated by a complex variety of variables (Huber et al., 2012), including public trust in the developer, decision-makers and community representatives (Ellis et al., 2007). 
A pivotal issue in any account of transition between energy pathways is that definitions of 'community renewables' are diverse and slippery. Community renewable energy projects can vary in terms of 'the community' that owns a stake (a local collective body, farmers and businesses, or individuals within a certain area?); the way that financial benefits flow between the project and 'the community' and patterns of energy use (purely for local use or for export to the grid?); and the extent to which community members were engaged in the project development process (Walker and DevineWright, 2008). Definition matters for the analysis presented here, in that definition is constitutive of the scope for expansion of 'community renewables'. Figure 1 seeks to capture some of the dilemmas and trade-offs at play. At one end of the spectrum there is a tight definition of 'community renewables', where electricity generation projects are owned by local, non-governmental bodies like co-operatives, development trusts or other social enterprises, who distribute revenues to local constituencies, often pursuing collective benefits above and beyond profits (Harnmeijer et al., 2012). However, looser definitions of 'community' renewables - with more flexible geographical and social ties between projects and publics - may be constitutive of larger projects and larger numbers of projects, not least because they can tap wider pools of funding. Thus a significant tranche of 'community ownership' of wind energy in Denmark and Germany stems from businesses (notably farmer cooperatives) and share ownership among the wider public, which encompasses private economic gain as much as democratic engagement (Lauber, 2012). The analysis here centres on narrow conceptions of community renewables - projects developed and owned by local communities and community bodies - but one should remain alert to how definitions are constructed and elided, not least in policy discourse. 


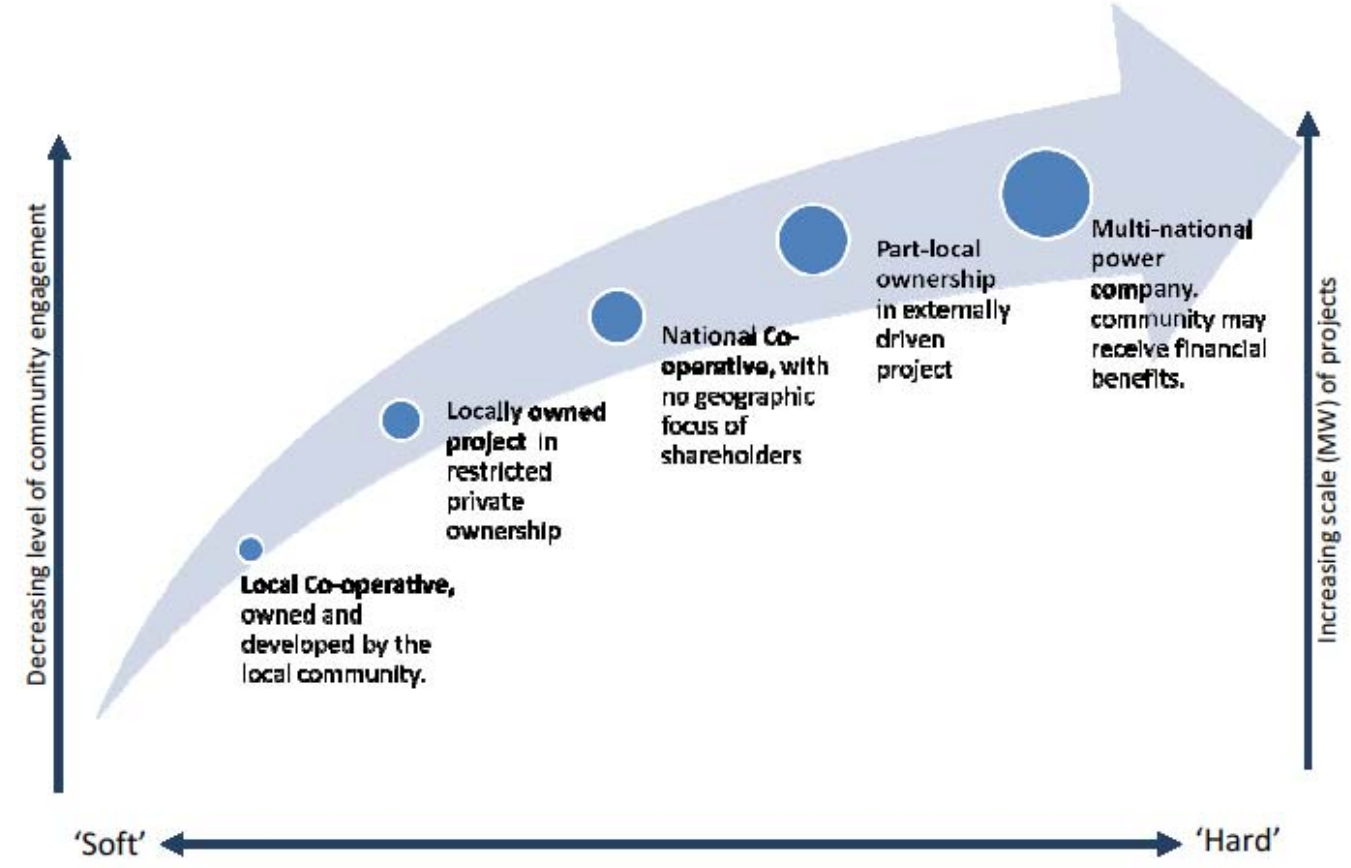

Figure 1: Scale-engagement trade-offs in community energy ${ }^{2}$

The diverse relations bound up in 'community renewables' becomes important when one considers how such activities might expand, from 'niches' to occupy a larger share of energy systems. Following Seyfang and Haxeltine (2012: 383-384) we might expect community renewables to grow and diffuse by:

- Replication (a growth in the number of initiatives);

- Up-scaling (a growth in the size of individual initiatives);

- Jumping scale (the transition of niche ideas into more mainstream settings, either by becoming attractive to audiences within the socio-technical regime, offering novel ideas for change, or being mobilised to challenge dominant modes of provision; see also Cox, 1998).

\footnotetext{
2 The figure pertains to the UK where it has become the norm for all electricity generation projects of any scale to deliver some form of community benefits; this may not be the norm in other countries.
} 
These are all important but under-examined processes (Smith, 2012). Indeed, the ability of 'niche actors' to affect wider policy arrangements is only beginning to be explored (Bomberg and McEwen, 2012; Seyfang and Haxeltine, 2012). To address this one must consider how community renewables intersect with the institutional arrangements of the socio-technical regime and wider political landscape. We now explore this in the context of community renewables in the UK.

\subsection{The UK policy context for community renewables}

\subsection{Moves towards community renewables?}

From 2000 onwards, there has been increased political interest in community renewables in the UK, evidenced by supportive statements in policy documents issued by successive UK governments, noting the potential of the sector and offering a range of supportive initiatives. This upswing appears more marked since 2008/9. Thus, the National Renewable Energy Action Plan for the UK anticipated that, to meet the 2020 targets of the EU Renewable Energy Directive, around 30\% of electricity demand would come from renewable sources, 'including 2\% from small-scale sources' (HM Government, 2009: 5). In 2014 the UK government produced its first community energy strategy (DECC, 2014). Many policies rolled out by UK central government have applied equally to Scotland and Wales. Nevertheless, interest in community renewables has arguably been more prominent among the devolved governments, especially Scotland. Since forming a majority Scottish Government in May 2011, the Scottish National Party (SNP) has set ambitious targets for renewable energy generation. To realise these goals, the First Minister recognised 'the need to get a buy-in, not just from the finance and energy sectors, but from the wider public as a whole' (Salmond, 2011). A specific 
target of attaining '500MW of community and locally owned renewable energy by 2020' was introduced (Scottish Government, 2011: 4), supported by the Scottish Community and Renewable Energy Scheme (CARES), which provides loans for the pre-planning costs of community renewable schemes. A number of factors underpin the momentum behind community renewables in Scotland. Devolution created a political opportunity to advance long-felt Scottish interests in giving rural, crofting communities more control over land-based assets, for which energy generation can be an attractive ingredient (Murphy, 2010). Scottish Governments also have a history of promoting renewable energy as a rural development strategy; an agenda pushed first by state development agency, Highlands and Islands Enterprise and, since 2008, by the NGO Community Energy Scotland.

The Welsh Government also introduced a support scheme in 2010, Ynni'r Fro, which offers advice and grant aid for the early development stages of community renewable energy projects. Twenty-four projects were anticipated to be in operation by 2015 . Progress with community renewables is slower in Northern Ireland - the region's first wind co-operative was only launched in 2012.

Other shifts at 'landscape' level (Geels, 2002) have had ambivalent effects on the prospects of community renewable energy. At the level of discourse, ideologies of 'localism' promoted by the 2010 UK Coalition Government encouraged community ownership of local assets, including energy, with Ministers claiming that the 'move to a sustainable society will be a local revolution too' (Barker, 2013). Measures associated with localism (in England) include new legal freedoms for local authorities that expand their scope to engage in energy generation and supply. More ambiguous is the effect 
since 2008 of economic austerity. Householders, community groups, housing providers and local authorities have come to view energy provision as a strategy for addressing rising fuel bills and increasing community resilience. However, drastic cuts in public spending and tightening bank lending have affected the funds available.

This policy attention needs to be put into the context of the total renewable electricity capacity installed in the UK, which exceeded 15.5GW by 2012 (DECC, 2012), with 5.7GW coming from onshore wind, $2.7 \mathrm{GW}$ from offshore wind, $1.7 \mathrm{GW}$ in solar photovoltaics (PV), and most of the rest from various hydro and bioenergy technologies (DECC, 2013). There is undeniably a large number and diversity of small-scale renewable energy facilities emerging across the UK, with some 247,000 installations registered as receiving the Feed-in Tariff (OFGEM, 2012). However, such statistics highlight how definition is constitutive of the scale of the community renewable sector. The capacity installed in renewable energy schemes owned wholly or partly by community groups in the UK remains very small: with one estimate suggesting a total by 2013 of about 60MW, two-thirds of this in Scotland, with 91\% in wind turbines (DECC 2014). Similarly, the Scottish Government has professed good progress towards its 500MW target, but 'individually owned' electricity is a higher proportion than 'communityowned'.

To explain this persistent slow development of community renewables in the UK, we now turn to two components of the socio-technical regime: first, systems of market support; second, the planning system.

\subsection{Systems of Market Support}


Many analysts have concluded that successive systems of market support for renewable energy in the UK have been more effectively exploited by large, incumbent energy businesses than smaller, new entrants (Lauber, 2012). This was true of the Renewable Obligation (R0), introduced in 2002, which imposed rising renewable targets on energy suppliers and introduced certificates issued to renewable energy generators which they could sell to suppliers or traders. The RO stimulated increased renewable energy investment, especially wind, but its design created risks and transactions costs that bigger organisations, able to fund projects 'off the balance sheet', were better placed to absorb (Woodman and Mitchell, 2011). The RO was not inaccessible to smaller-scale and community-owned renewable energy projects, but the vast majority of UK onshore wind capacity is in the ownership of a small number of large, international utilities (Cumbers et al., 2013). This pathway seems likely to be perpetuated by the 2011 Electricity Market Reforms (EMR), driven by UK central government, which is seeing the RO system phased out and replaced with a system of Contracts for Difference (CfD). Although ostensibly offering greater revenue predictability to developers, concerns have been raised about that the complexity of the proposed arrangements will again make it difficult for new community entrants to access (Harvey, 2012).

Overall, devolution has scarcely effected this dimension of the socio-technical regime. In theory, the Northern Ireland Executive has the autonomy to design its own system of market support but did not do so, because of financial dependence on UK-wide pool of financial resources. While the reforms did provoke some assertive exchanges between Scotland's First Minister and Westminster, this resistance was not sustained and, in any case, Scottish concerns focused on the risks to renewable energy expansion generally, 
not specific risks that the reforms might pose to small-scale generators and community projects.

Capital availability is vital for community renewable projects, yet the uncertainties of the RO compounded the unwillingness of UK banks to provide affordable loans to this part of the sector (Mendonça, 2011; Harnmeijer et al., 2013). In this context, government-backed grant and loan schemes have become central to supporting the development of community renewables in the UK. The first decade of the $21^{\text {st }}$ century saw a proliferation of initiatives designed to support community-level work on low carbon energy, offering advice and grant aid to address the up-front costs (Park, 2012). However, this proliferation of efforts does not mean that the overall system of support across the UK has been significant, expanding or consistently helpful. The funds usually required competitive bidding, or only covered part of the costs, and were regularly over-subscribed. As a consequence, these support programmes have tended to favour existing social enterprises or established organisations. Many of the grant schemes in operation over the previous decade were wound up during 2010 and 2011 as fiscal austerity began to bite (Gubbins, 2011). The CARES and Ynni'r Fro initiatives of the Scottish and Welsh governments can be seen as modest palliatives to this wider UK context.

\subsection{The Planning System and Land Control}

New energy facilities need to obtain an array of consents, with planning permission often regarded as the greatest 'hurdle' to renewable projects in the UK. Proposals by community groups are treated on the same basis as those from a private developer: furthermore, the traditional focus on land-use related 'material considerations' means 
that decision-makers cannot formally consider the level of financial community benefits offered by a scheme, lest this should be perceived as 'paying for planning permission' (Strachan and Jones, 2012).

In practice, planning processes can be highly politicised and the prospect of benefits to local communities can influence decisions: see for example the positive planning consent decisions for the Bro-Dyfi Community Renewables project in Wales (Cowell et al., 2008). However, there are no guarantees. Renewable energy proposals in rural locations in the UK are always at risk of opposition due to their impacts, whether community projects or not, and the distribution of benefits from 'community renewables' can itself be a point of contention (Walker 2008). Moreover, one cannot assume that the proponents of community renewables are better organised, resourced and networked than potential opponents, especially anti-wind power groups (Smith, 2012); see 4.3 below.

To date then, there have been few formal policy resources within the UK planning system that explicitly give advantages to community renewables and might therefore help this 'niche' activity to expand. Devolution within the UK has scarcely affected this situation. Although successive revisions to planning policy in Wales and Scotland have highlighted the scope for renewable energy projects to deliver benefits to communities, these maintain the UK convention that financial benefits should not be treated as material to planning decisions (Scottish Government 2010; WAG 2005). However, planning policy in England is in significant flux. Some measures appear supportive of soft energy paths, notably national policy guidance encouraging local authorities to 'support community-led initiatives for renewable and low carbon energy' (DCLG 2012a: 
para 97). Set against this, onshore wind energy has been threatened with tighter planning controls (HM Government, 2013), a step which could affect community projects as much as major commercial schemes. The net effect of these measures - both of which might be legitimised as aspects of 'localism' - is difficult to predict. There have also been moves across England, Scotland and Wales to extend the range of renewable energy projects that can be developed without planning permission, but this still mostly benefits 'micro-generation' (i.e. very low-capacity renewable energy projects), such as wind turbines up to a certain maximum height (DCLG, 2012b). Such dispensations do not help community renewables up-scale, although projects that proceed through the replication of micro-generation facilities may become easier.

In other respects, planning reforms have tended to reinforce the power of the dominant socio-technical regime, as successive governments across the UK have taken more robust steps to expedite large-scale energy developments. In England, Scotland and Wales, applications for electricity generating facilities of 50MW are determined by special, centralised procedures which diminish the significance of localised conflict around applications. In Scotland, a central consents unit manages the application process and issues permissions on behalf of Scottish Ministers. Evidence suggests that applications for wind farms to this procedure enjoy a higher consent rate than smaller schemes submitted to local planning authorities (Reform Scotland, 2011). For England, Wales, 'National Policy Statements' have been introduced to specify the need for major renewable energy infrastructure, which cannot then be questioned as individual projects come forward (HM Government, 2013). This is linked to the introduction of strict time schedules for the running of public examinations and issuing of decisions. The Welsh Government have also created a new layer of strategic planning policy which confers a 
presumption in favour of large-scale wind farms (25MW upwards) within demarcated 'strategic search areas' (WAG 2005).

Given the spatially extensive nature of many renewable energy resources, land rights also critically affect the development of the sector. Control over land helps to explain why farmers and land-owning organisations have been quicker to exploit the opportunities of renewable energy than community groups. One important intermediary in the UK is the state forestry bodies, which manage public forests on behalf of the various devolved governments. The Forestry Commission in Wales and Scotland has adopted supportive stances towards community-owned renewables on their forest estates, but they have also divided its wind energy potential into very large blocks and encouraged bids for the development rights. A similar approach is emerging in Northern Ireland. The main effect of such strategies is, again, to channel opportunity towards major corporate actors.

\section{Pathways to community renewables in a corporate energy world}

These components of the socio-technical regime for renewables help to explain the limited development of a community sector in the UK. Schemes that are wholly developed and owned by communities remain few in number and relatively small in scale (most are below 10MW). Given that regime conditions seem unhelpful to community renewables, perhaps pathways which entail some form of hybridity between community ownership and major, corporate actors would have more scope for expansion? Two pathways warrant closer examination - joint ownership ventures and community benefit funds - before turning to consider the actors that might 'jump scale' to promote the cause of community renewables within wider governance architecture. 


\subsection{Joint Ownership Ventures}

Joint ventures arise when a local organisation and a commercial developer enter into a legal relationship. The reasons for pursuing such an arrangement can be outlined as follows. The commercial developer, by involving the local community, aims to tap into local knowledge and concerns and, hopefully, foster community support at an early stage. For the local community a joint venture arrangement may provide an avenue for acquiring a share in a renewable energy project that circumnavigates any lack of skills and capital within the community, and allow greater influence over the management of environmental impacts. The commercial developer can take the lead on issues where they have expertise, such as securing grid connections, negotiating market support, as well as financing initial project development costs and bearing the main financial risks: all issues which communities find problematic (Fermanagh Trust, 2012).

There are diverse models of joint ownership from which wider lessons could be derived. For example, the 10MW Neilston windfarm, East Renfrewshire, Scotland, is a Limited Liability Partnership arrangement in which the commercial developer (Carbon Free Developments Ltd) owns 50.1\% and the Neilston Development Trust (a social enterprise organisation) owns 49.9\%. Also in Scotland, Falck Renewables (the developer) has allowed the Fintry Development Trust to acquire a single $2.5 \mathrm{MW}$ wind turbine in a larger development of 15 turbines. The income generated from the wind turbine is being used to pay off the loan, with surplus funds being used to support the many activities of the Trust (Gubbins, 2010; Fermanagh Trust, 2012). 
Whatever potential joint venture arrangements may offer for replicating and up-scaling community ownership of renewables, such models are not widespread in the UK. Harnmeijer et al. (2013) estimate that just a third of community renewable energy capacity is jointly owned. There remains an overwhelming preference by commercial developers to go it alone or, to act in larger-scale corporate consortia. Some commercial developers fear that joint arrangements can make projects more complex, and undermine profitability. Given that many wind energy projects are developed by one company and then sold on - a by-product of a pathway dominated by international, commercial operators - community stakes may be seen as an encumbrance. Local communities, too, can be reticent about joint ventures. An obvious problem is that they can end up having a minority stake in the project with less control than if they went it alone, which may be unpalatable where local autonomy and grass-roots activism are central to communities' motivations (Seyfang and Haxeltine, 2012). As an energy development pathway, joint ventures tie the expansion of community renewables to the preferences of larger, commercial operators.

\subsection{Community Ownership via Community Benefits Provision}

A key feature of the UK's dominant renewable energy pathway has been the provision of 'community benefits' from conventional, commercial wind energy projects. These have been defined as, "'goodwill" contributions donated by a developer for the benefit of communities affected by development'3, although the rationale and merits of such payments has been contested (Cowell et al., 2011). Community benefits can take a variety of forms, though typically consists of an annual fund paid by the operator to

\footnotetext{
${ }^{3}$ http://www.highland.gov.uk/livinghere/communityplanning/communitybenefit/ (Accessed 24 ${ }^{\text {th }}$ November 2014.
} 
some representative organisation for those communities nearest the windfarm. Importantly, the scale of community benefit funds has increased since the 1990s: payment norms have risen from $£ 1000 / \mathrm{MW}$ of installed capacity per annum to levels frequently topping $£ 5000 / \mathrm{MW}$. As wind farms have also increased in size, there are now a growing number of communities in receipt of funds exceeding $£ 100,000$ per annum.

Most funds have been used to support local 'good causes' in the vicinity of the wind farm, but some have come with stipulations that a proportion of the money should be spent on sustainable energy measures - and here is the connection to community renewables. One could argue that community benefit funds are an under-exploited source of money for funding community-owned renewables. There are already instances where this has occurred: community funds from the Carno wind farms in midWales have been used to support biomass boilers in community buildings. The scale of funds now being channelled through community benefit mechanisms bears comparison with the scale of government grant/loan schemes for community renewables outlined above. For example the level of community benefits expected from wind farms on national forest land in Wales is likely to exceed $£ 70$ million over 25 years, while Ynni'r Fro has a budget of $£ 15$ million over five years (Welsh Government, 2012).

Governments across the UK have taken steps to boost the level of community benefits: by fostering greater transparency and learning through the creation of an online community benefits register (as in Scotland; since transferred to England (DECC, 2014)); or pressing the industry to set $£ 5000 / \mathrm{MW}$ as the minimum for community 
benefits from onshore wind projects (HM Government, 2013) ${ }^{4}$. In line with conceptions of 'localism', but targeting a different conception of 'community', is the provision for England that local authorities can retain all of the business rate income from new renewable energy projects in their area (Smith, 2013).

Potentially then, community benefit funds provide a resource for local energy initiatives. However, one could hardly badge community benefits as a vehicle for systemic change in energy provision. Community benefits are not mandatory; to make them so would challenge the institutional norms of the planning system, in which consent is not to be 'bought' (Strachan and Jones, 2012). Although the scale of funds is higher than levels achieved in the past, the $£ / \mathrm{MW}$ flowing to communities remains lower than with full community ownership. Moreover, any requirement that a proportion of community benefits must be spent on community renewables would need to confront the widespread reluctance of communities and developers to see their flexibility constrained by 'external' spending rules (Cowell et al., 2011).

Viewed through transitions frameworks, the major commercial and policy rationale for community benefits has been to improve the social acceptability of the dominant pathway of wind energy development and reduce local opposition. In practice, it is not clear that provision of such benefits affects public perceptions of the distribution of costs and benefits arising from major projects. Since 2010 there has been a shift in government policy discourse towards a principle that communities should 'share the benefits' of major energy development (HM Government, 2013), including bringing

\footnotetext{
${ }^{4}$ Community benefits of wind energy projects only began to appear on the political agenda in Northern Ireland in 2012-2013.
} 
forward the Danish model of compulsory share issues for local people of up to $20 \%$ of the project ownership (DECC, 2014). This hints at a more justice-based, redistributive agenda, but it is one in which communities are engaged in energy development through some entitlements to benefits from the conventional, private, commercial exploitation of resources. This is as opposed to local organisations or people owning a substantial stake or indeed all of the equity of a project and therefore having full decision-making control.

\subsection{New bearers of the community renewables agenda?}

To understand energy transitions one needs to look at the social actors involved, not simply the technological and economic dimensions. Indeed, one factor perpetuating the marginal position of community renewables in the UK is the failure to cultivate actors that are willing and able to challenge the power of major, incumbent energy businesses and policies that constitute the dominant socio-technical regime (Lauber, 2012). Part of the issue lies in the tendency of actors engaged in community renewables to focus on local arenas. Financial and time resources are important constraints: simply developing and managing a community energy project is often the main goal of the actors concerned, leaving little scope to lobby government or create networks. In so far as there is a political imagination, it often relates to community-level sustainability, by mobilising locally, rather than 'jumping scale' to challenge wider structural constraints.

This leaves policy action by the community renewables sector rather dependent on intermediary bodies. A significant player in terms of scale and capacity has been Community Energy Scotland, as introduced above. In Wales, steps have been taken to emulate Scotland by creating Community Energy Wales (formed June 2012) to 
represent and promote the sector. January 2012 marked the inauguration of the 'Community Energy Coalition'; an England-based coalition bringing together ethical banks (such as the Cooperative), and environmental NGOs such as the National Trust, with the express goal of widening the significance of community renewables to contribute to energy targets. Other networks are also important, such as the Communities and Climate Change Action Alliance (CCAA) and the Community Energy Practitioners Forum. These intermediaries have engaged in policy debates, for example, pressing DECC to modify the FIT in ways which would help community renewables, and through central government's Community Energy Contact Group. This idea of linking decarbonisation with social control of energy is taking foothold as a dispersed civic movement for 'Energy Democracy”.

Although intermediary bodies are emerging, their development has been late and slow. Limited resources also affect their scope to act: neither Community Energy Wales nor the CCAA have any budget ${ }^{6}$. Community Energy Scotland responds to government policy consultations, and serves in policy formulation committees in DECC, but their central role and most of their funding is concerned with helping communities to develop projects. At the same time, the community sector is less well-represented in core networks where major policy issues are discussed. It is also problematic that the main representative bodies for the renewable energy sector, such as RenewablesUK or the Northern Ireland Renewables Industry Group have their agenda dominated by the major companies that make up their main membership.

\footnotetext{
${ }^{5}$ See for example http://www.renewablecommunities.org/ http://cleantechnica.com/2013/05/14/energy-democracy-video-campaign/ (Accessed 24 ${ }^{\text {th }}$ November 2014)

${ }^{6}$ Personal Communications 28 ${ }^{\text {th }}$ March 2013; 22 ${ }^{\text {nd }}$ October 2013.
} 
Turning to the devolved governments themselves, there is some evidence that devolution has enabled new party platforms to form around community renewables. In Scotland, the manifestos of the SNP in the 2007 and 2011 Scottish Government elections expressed support for greater 'bottom up' engagement in Scotland's 'energy revolution', but this sits alongside a significant emphasis on the expansion of industrial-scale, commercial energy projects - in renewables and hydrocarbons - as part of an energy export growth agenda for Scotland. Within the National Assembly for Wales, both Plaid Cymru and the Liberal Democrats went into the 2011 election promoting community ownership of renewable energy development. This position has been less prominent in the platforms of the Welsh Labour Party, which prefers to emphasise "benefits to communities', but it is Labour that has dominated successive Welsh Governments. The manifestos of parties in Northern Ireland have tended to frame renewable energies in terms of helping farm diversification and the rural economy, not as anything more transformative.

\section{Conclusions}

When making comparisons with other European countries it is clear that community renewables are only playing a very small part in helping to secure EU renewable energy and broader climate change targets in the UK. Indeed, our conclusions reaffirm previous analyses that community renewables remain weakly developed in the UK; especially when one considers definitions of community renewables which entail high levels of community ownership and involvement in project development. While the concept of community renewables is now more recognised, the trajectory of actual development has been one of slow replication and modest up-scaling. The trend in the 
UK is for community participation in renewables to be limited mainly to community benefits provision, which represents a redistribution of some of the profits rather than a fundamentally different pattern of control through local ownership.

This leads to important questions about the sensibility of seeing community renewables as a route for transforming systems of energy provision. Social conditions are an important part of the 'landscape' too, in that the finance, skills and other social capital to develop such projects is unevenly available across society, such that the number of communities with the capacity to engage in energy production is limited (Malhotra, 2006). Nevertheless, one should still be alert to the processes by which such pathways are kept to the margins. In the UK, but also other countries like Australia, France and the USA, this can be attributed to the persistence of key features of the socio-technical regime for electricity provision, which continues to favour large corporations and major facilities. Indeed key structuring elements - in systems of market support and planning policy in the UK - have arguably become more supportive of hard energy paths in the years since 2000, not less. One partial exception to this pattern stems from the UK Feed-in Tariff, but it is important to recognise how this intersects with definitions of community renewables. Small-scale renewable energy projects have benefited, but mainly householders, businesses, farms and public bodies, rather than community groups.

Our analysis supports conclusions of wider relevance. It reinforces Verbong and Loorbach's perspective (2012) that analysts of energy transitions need to look beyond the niche and innovation dimensions of community renewables, to examine the persistence and adaptability of socio-technical regimes, and the way in which they 
configure the scope for alternatives. Our analysis has explored opportunities for extending community renewables through various hybrid pathways, involving joint ventures with commercial projects, or using the community benefit funds provided by major developments (see Table 2). While of some value, such strategies are limited by the fact that they represent 'community energy as viewed from the regime, and asking what they offer businesses and policy-makers' (Smith 2012: 198). They fit into a wider policy narrative in the UK which emphasises that 'communities should benefit' from energy transition, rather than the overall pathway being softened to allow communityowned initiatives a more central role. An obvious limitation of hybrid strategies, in terms of energy transition, is that they trap community renewables in a dependence relationship with harder energy paths, and this is an important lesson that other countries should note.

\begin{tabular}{|c|c|c|c|c|}
\hline Pathway & Points of definition & $\begin{array}{l}\text { Advantages for } \\
\text { community } \\
\text { renewables }\end{array}$ & Disadvantages & $\begin{array}{l}\text { Transition } \\
\text { potential? }\end{array}$ \\
\hline $\begin{array}{l}\text { Community- } \\
\text { developed and } \\
\text { community- } \\
\text { owned }\end{array}$ & $\begin{array}{l}\text { Schemes in which } \\
\text { local community takes } \\
\text { leading role, full } \\
\text { ownership and } \\
\text { benefits accrue locally }\end{array}$ & $\begin{array}{l}\text { High level of } \\
\text { community } \\
\text { control; scope to } \\
\text { tailor to local } \\
\text { needs }\end{array}$ & $\begin{array}{l}\text { Exposes limited } \\
\text { resources and } \\
\text { skills of } \\
\text { community; } \\
\text { dependence on } \\
\text { grants }\end{array}$ & $\begin{array}{l}\text { Limited scope to } \\
\text { replicate or up- } \\
\text { scale in wider } \\
\text { policy } \\
\text { environment }\end{array}$ \\
\hline Joint ownership & $\begin{array}{l}\text { Community acquires } \\
\text { share of commercially- } \\
\text { developed project }\end{array}$ & $\begin{array}{l}\text { Involvement of } \\
\text { commercial } \\
\text { operator reduces } \\
\text { problems of skills } \\
\text { and capital }\end{array}$ & $\begin{array}{l}\text { Reduced } \\
\text { community } \\
\text { control; } \\
\text { opportunities } \\
\text { framed by } \\
\text { commercial } \\
\text { partner }\end{array}$ & $\begin{array}{l}\text { By-product of } \\
\text { dominant, } \\
\text { commercial } \\
\text { renewable } \\
\text { energy pathway }\end{array}$ \\
\hline $\begin{array}{l}\text { Community } \\
\text { benefit funds }\end{array}$ & $\begin{array}{l}\text { Essentially a mode of } \\
\text { funding community } \\
\text { renewables rather } \\
\text { than a pathway in its } \\
\text { own right }\end{array}$ & $\begin{array}{l}\text { Provides funds } \\
\text { rather than loans } \\
\text { for upfront costs; } \\
\text { can be coupled } \\
\text { with revenue } \\
\text { support }\end{array}$ & $\begin{array}{l}\text { Linked to } \\
\text { windfarm } \\
\text { locations; } \\
\text { competing local } \\
\text { claims on funds }\end{array}$ & $\begin{array}{l}\text { By-product of } \\
\text { dominant, } \\
\text { commercial } \\
\text { renewable } \\
\text { energy pathway }\end{array}$ \\
\hline
\end{tabular}

Table 2: Pathways to expanding community renewables in the UK - a summary 
Another important lesson relates to the importance of government action in shaping energy development pathways (Hodson and Marvin, 2013). Our analysis has sought to disaggregate the UK picture and consider whether political devolution has affected the development of community renewables or, equally important to the prospects of transition, destabilised the prevailing models of electricity provision. Our research found some evidence for the former but little for the latter. The governments of Scotland, Wales and Northern Ireland have provided support for small-scale and community-focused renewables, with successive Scottish Governments being particularly helpful. Yet in practice the devolved governments have broadly supported the maintenance of conventional, large-scale electricity development pathways and indeed enhance them, in the spheres of market support, planning reforms and by adding additional layers of political legitimacy. Overall, the activities of the UK's subnational governments can be read as adding to the spatial adaptability of prevailing socio-technical regimes, rather than destabilising them.

This leads to a different, less frequently explored aspect of the prospects for significantly more decentralised, communitarian systems of energy provision. Instead of focusing on the scope for niche expansion, the prospects of such systems depend on the extent to which core actors - central governments, major corporations - continue to believe in the efficacy and deliverability of hard energy paths. Such beliefs remain intact in the UK. Certainly, social conflict around onshore wind has prompted questions about this technology, and concerns about delivery and social acceptability have sustained policy-makers' interest in helping communities benefit from new energy infrastructure. Support for community renewables is a beneficiary of such concerns, but it is not the only consequence. It has also led to the UK curtailing the scope for contesting hard 
energy paths, by streamlining the planning system for major energy infrastructure, including new nuclear and gas-fired capacity. At EU-level, too, faith in the expansion of industrial-scale energy provision remains undiminished. This is exemplified by moves to create a European supergrid, fostering market integration between member states and the large-scale exploitation of major, capital-intensive energy sources like marine renewables and solar capacity south of the Mediterranean (European Commission, 2011). Such agendas seem most likely to entrench the position of incumbent actors.

Finally, further research is required to assess whether community renewables and its proponents are anything other than marginal to debates about these policy directions and in driving wider system transformation in the UK, and beyond.

\section{References}

Alkemade, F, Hekkert, MP, Negro, SO. 2011. Transition policy and innovation policy: friends or foes? Environmental Innovation and Societal Transitions 1(1): 125-129.

Barker, G. 2013. Foreword in ResPublica.

http://www.respublica.org.uk/documents/yqq Community\%20Renewables\%20Econo my.pdf. (Accessed 15th November 2014).

Bomberg, E, McEwen, N. 2012. Mobilizing community energy. Energy Policy 51(12): 435-444.

Cowell, R, Bristow, G, Munday, M, Strachan, P. 2008. Wind Farm Development in Wales: Assessing the Community Benefits, A Research Project for the Welsh Assembly Government (WAG). WAG: Cardiff. 
Cowell, R, Bristow, G, Munday, M. 2011. Acceptance, acceptability and environmental justice - the role of community benefits in wind farm development. Journal of Environmental Planning and Management 54(4): 539-557.

Cowell, R, Ellis, G, Sherry-Brennan, F, Strachan, PA, Toke, D. 2013. Delivering Renewable Energy Under Devolution: Initial Findings Summary Report. University of Cardiff: Cardiff.

Cox, K. 1998. Spaces of dependence, spaces of engagement and the politics of scale, or: looking for local politics. Political Geography 17(1):1-23.

Cumbers, A, Danson, M, Whittam, G, Morgan, G, Callaghan, G. 2013. Repossessing the Future. A Common Weal Strategy for Community and Democratic Ownership of Scotland's Energy Resources. Jimmy Reid Foundation: Biggar.

DCLG (Department for Communities and Local Government), 2012a. National Planning Policy Framework. DCLG: London.

DCLG (Department for Communities and Local Government), 2012b. Permitted Development Rights for Small-scale Renewable and Low Carbon Energy Technologies, and Electric Vehicles Charging Infrastructure. Consultation. DCLG: London.

DECC (Department of Energy and Climate Change). 2011. UK Renewable Energy Roadmap. DECC: London.

DECC (Department of Energy and Climate Change), 2012. Energy Trends, September. DECC: London.

DECC (Department of Energy and Climate Change). 2013. Digest of UK Energy Statistics (DUKES). DECC: London.

DECC (Department of Energy and Climate Change). 2014. Community Energy Strategy. Full Report. DECC: London. 
DTI (Department of Trade and Industry). 2003. Our Energy Future.

http://webarchive.nationalarchives.gov.uk/+/http://www.berr.gov.uk/files/file10719. pdf (Accessed 12th September 2014).

Edelman Trust. 2014. Edelman Trust Barometer 2014, UK Data.

http://www.slideshare.net/Edelman UK/energy-trust-barometer-2014 (Accessed 12th November 2014).

Ellis, G, Barry, J, Robinson, C. 2007. Many ways to say no, different ways to say yes: applying Q-methodology to understand public acceptance of wind farm proposals. Journal of Environmental Planning and Management 50(4): 517-551.

European Commission. 2011. Energy Infrastructure. Priorities for 2020 and Beyond - A Blueprint for an Integrated European Energy Network. DGEn, Luxembourg: European Union.

Fermanagh Trust. 2012. Maximising Community Outcomes from Wind Energy Developments. Fermanagh Trust: Enniskillen.

Geels, FW. 2002. Technological transitions as evolutionary reconfiguration processes: a multi-level perspective and case-study. Research Policy 31(8-9): 1257-1274.

Gubbins, N. 2010. The Role of Community Energy Schemes in Supporting Community Resilience, JRF briefing paper on Community Assets. JRF: York.

Harnmeijer, A, Harnmeijer, J, McEwen, N, Bhopal, V. 2012. A Report on Community Renewable Energy in Scotland. SCENE Connect: Edinburgh.

Harnmeijer, J, Parsons, M, Julian, C. 2013. The Community Renewables Economy. A ResPublica Green Paper. ResPublica Trust: Lincoln. 
Harvey, F. 2012. Plans to reform electricity markets 'unworkable', says green

businesses. The Guardian, $15^{\text {th }}$ May.

http://www.guardian.co.uk/environment/2012/may/15/reform (Accessed 16 ${ }^{\text {th }}$ May 2014)

HM Government. 2009. National Renewable Energy Action Plan for the United Kingdom. https://www.gov.uk/government/uploads/system/uploads/attachment data/file/478 71/25-nat-ren-energy-action-plan.pdf, (Accessed 10 th July 2014).

HM Government. 2013. Press release. Onshore Wind: Communities to Have a Greater Say and Increased Benefits, $6^{\text {th }}$ June 2013. DECC and DCLG: London.

Hodson, M, Marvin, S. 2013. Low Carbon Nation. Earthscan: London.

Hopwood, B, Mellor, M, O’Brien, G. 2005. Sustainable Development: Mapping Different Approaches. Sustainable Development 13(1): 38-52.

Huber, S, Horbarty, R, Ellis, G. 2012. Social acceptance of wind power projects: learning from trans-national experience pp. 215-234, in Szarka J, Cowell R, Ellis G, Strachan PA, Warren C (eds) Wind Power, Society and Governance. Lessons for Future Sustainable Energy. Palgrave Macmillan: Basingstoke.

Lauber, V. 2012. Wind power policy in Germany and the UK: different choices leading to divergent outcomes pp. 38-60, in Szarka, J, Cowell, R, Ellis, G, Strachan, PA, Warren, C. (eds) Learning From Wind Power. Governance, Societal and Policy Perspectives on Sustainable Energy. Palgrave Macmillan: Basingstoke.

Li, W, Rubin, T, Onyina, P. 2012. Comparing solar water heater popularization policies in China, Isreal and Australia: the roles of governments in adopting green innovations. Sustainable Development 21(3): 160-170. 
Lovins, AB. 1977. Soft Energy Paths: Toward a Durable Peace. Penguin: Harmondsworth.

Lybæk, R, Budde Christensen, T, Kjær, T. 2013. Governing innovation for sustainable development in the Danish biogas sector - a historical overview and analysis of innovation. Sustainable Development 21(3): 171-182.

Malhotra, P. 2006. Management of community-based energy interventions in rural areas of India: issues and perspectives. Sustainable Development 14(1): 33-45.

Meadowcroft, J. 2009. What about the politics? sustainable development, transition management, and long term energy transitions. Policy Sciences 42(4): 323-340.

Mendonça, M. 2011. The UK Feed-in Tariff: A User Survey, Working Paper. Birkbeck College: University of London.

Murphy, J. 2010. At the Edge: Community Ownership, Climate Change and Energy in Scotland, A Briefing Paper. JRF: York.

Murphy, J, Smith, A. 2013. Understanding transition-periphery dynamics: renewable energy in the Highlands and Islands of Scotland. Environment and Planning A 45(3): 691-709.

Ngar-yin Mah, D, Hills, P. 2012. Collaborative governance for sustainable development: wind resource assessment in Xinjing and Guangdon provinces, China. Sustainable Development 20(2): 85-97.

OFGEM (Office of Gas and Electricity Markets). 2012. Feed-in Tariff: Annual Report 20112012. 175/12. OFGEM: London.

Park, J. 2012. Fostering community energy and equal opportunities between communities'. Local Environment 17(1): 387-408.

Reform Scotland. 2011. Powering Scotland. Reform Scotland: Edinburgh. 
Rojanamon, P, Chaisomphob, T, Bureekul, T. 2013. Public participation in development of small infrastructure projects. Sustainable Development 20(5): 320-334.

Salmond, A. 2011. Scottish Low Carbon Conference Opening Address. http://www.scotland.gov.uk/News/Speeches/SLICsept27-2011\# (Accessed 12 September 2014).

Scottish Government. 2010. Scottish Planning Policy. Scottish Government: Edinburgh. Scottish Government. 2011. Routemap for Renewable Energy in Scotland. http://www.scotland.gov.uk/Publications/2011/08/04110353/0 (Accessed 12th September 2014).

Seyfang, G, Haxeltine, A. 2012. Growing grassroots innovations: exploring the role of community-based initiatives in governing sustainable energy transitions. Environment and Planning C: Government and Policy 30(3), 381-400.

Shove, E, Walker, G. 2007. CAUTION! Transitions ahead: politics, practice, and sustainable transition management. Environment and Planning A 39(4): 763-770.

Smith, A. 2012. Civil society in sustainable energy transitions pp.180-202, in Verbong, G, and Loorbach, D (eds. 2012). Governing the Energy Transition. Reality, Illusion or Necessity? Routledge: London.

Smith, L. 2013. Planning for Onshore Wind Farms. SN/SC/4370. House of Commons Library: London.

Smith Stegen, K, Seel, M. 2013. The winds of change: how wind firms assess Germany's energy transition. Energy Policy 61(10): 1481-1489. 
Späth, P, Rohracher, H. 2012. Local demonstrations for global transitions-dynamics across governance levels fostering socio-technical regime change towards sustainability. European Planning Studies 20(3): 461-479.

Steinhilber, S, Wells, P, Thankappan, S. 2013. Socio-technical inertia: understanding the barriers to electric vehicles. Energy Policy 60(9): 531-539.

Strachan, PA, Jones R. 2012. Navigating a minefield? wind power and local community benefit funds pp.180-202, in Szarka, J., Cowell, R., Ellis, G., Strachan, PA, Warren, C (eds). Learning From Wind Power. Governance, Societal and Policy Perspectives on Sustainable Energy. Palgrave Macmillan: Basingstoke.

Strachan, PA, Toke, D, Lal, D. 2010. Assessing national patterns of wind ownership pp. 117, in Strachan, PA, Toke, D, Lal, D. (eds). Wind Power and Power Politics: International Perspectives. Routledge, New York.

Turcu, C, Rydin, Y. 2012. Planning for change in urban energy systems, Town and Country Planning May: 227-232.

Verbong, G, Loorbach, D. 2012. Governing the Energy Transition. Reality, Illusion or Necessity? Routledge: London.

WAG (Welsh Assembly Government). 2005. Technical Advice Note 8: Planning for Renewable Energy. Cardiff: WAG.

Walker, G. 2008. What are the barriers and incentives for community owned means of energy production and use? Energy Policy 36(12): 4401-4405.

Walker, G, Devine-Wright, P. 2008. Community renewable energy: what should it mean? Energy Policy 36(12): 497-500. 
Welsh Government. 2012. Climate Change Strategy for Wales. First Annual Progress Report. Welsh Government: Cardiff.

Woodman, B, Mitchell, C. 2011. Learning from experience? the development of the Renewable Obligation in England and Wales, 2002-2010. Energy Policy 39(7): 39143921. 